\title{
Penggunaan Media Film Dokumenter dalam Keterampilan Berbicara Bahasa Indonesia pada Siswa Bipa Tingkat Madya di Universitas Trisakti ${ }^{1}$
}

\author{
Dewi Nastiti Lestari ${ }^{2}$
}

\begin{abstract}
Abstrak
Hasil penelitian menunjukkan bahwa kegiatan berbicara dengan teknik diskusi melalui penggunaan film dokumenter sangat membantu atau memotivasi siswa untuk berpikir logis dan berbahasa target, bahasa Indonesia. Permasalahan keterampilan berbicara siswa yang ditemui pada program BIPA di Universitas Trisakti antara lain terdapat kekurangtepatan pada beberapa poin kebahasaan berikut, seperti: pelafalan saat merangkai kata menjadi kalimat; penggunaan kata dalam konteks kalimat; penggunaan kata sambung intrakalimat dan antarkalimat; pengujaran kalimat majemuk, serta pemahaman konteks ujaran kawan tutur. Hal tersebut memunculkan pertanyaan: (a) Bagaimana meningkatkan keterampilan berbicara dalam bahasa Indonesia melalui media film dokumenter? (b) Apakah keterampilan berbicara bahasa Indonesia siswa BIPA tingkat madya dapat ditingkatkan melalui media film dokumenter? Keterampilan berbicara yang dimaksudkan adalah kegiatan yang bertujuan untuk berkomunikasi dengan kawan bicara secara logis dan wajar dengan menggunakan pelafalan yang tepat, bertata bahasa yang benar, penggunaan kosakata yang tepat, kelancaran pengucapan yang baik, dan terdapat pemahaman antarkawan bicara. Sementara itu, penggunaan media film dokumenter yang dimaksud merupakan alat bantu pembelajaran efektif untuk menyampaikan materi yang berisikan pengenalan budaya dan realita sosial dengan tujuan untuk menjembatani proses komunikasi pada saat-saat tertentu, seperti terdapat kesenjangan antara bahasa dan budaya siswa asing. Dalam hal ini digunakan film dokumenter yang disesuaikan dengan topik BIPA pada tingkat madya. Film dokumenter yang digunakan diperoleh dari Yayasan Masyarakat Mandiri Film Indonesia, sebuah komunitas film Indonesia yang di dalamnya terdapat kerja sama antara In-Docs dan The Ford Foundation. Bahasan dalam makalah ini memfokuskan pada penjelasan atas pertanyaan penelitian tersebut. Data yang digunakan dalam kajian ini berdasarkan hasil penelitian tindakan pada program BIPA, Kerjasama Negara Berkembang di Universitas Trisakti.
\end{abstract}

\footnotetext{
${ }^{1}$ Pernah disajikan pada KIPBIPA VII di Universitas Indonesia

2 Pembantu Pimpinan pada Kantor Bahasa Prov. NTB
} 


\section{Pendahuluan}

Program BIPA di Universitas Trisakti merupakan rintisan dari Program Kerjasama Negara Berkembang (KNB) di bawah Kementerian Pendidikan Nasional. Pada tahun 2010 Universitas Trisakti mendapatkan tujuh siswa yang berasal dari berbagai negara. Namun, seiring dengan berjalannya waktu, siswa yang masih mengikuti program BIPA berjumlah enam orang. Pengurangan siswa tersebut disebabkan karena terdapat ketidaksesuaian antara program S2 di Universitas Trisakti dengan peminatan bidang keilmuan siswa tersebut. Tujuan diadakan kelas BIPA pada tahun ini dan juga tahun sebelumnya di Universitas Trisakti adalah untuk memperlancar komunikasi siswa dalam bahasa Indonesia yang nantinya akan digunakan mereka pada saat menjalankan program studi di universitas tersebut. Keenam siswa yang mengikuti program BIPA berasal dari berbagai negara, seperti: Kamboja, Thailand, Madagaskar, Papua Nugini, dan Spanyol. Mereka juga berasal dari latar pendidikan yang berbeda. Adapun latar belakang pendidikan mereka terdiri atas bidang ekonomi, geologi, dan bahasa.

\subsection{Permasalahan Keterampilan Berbicara Siswa BIPA Tingkat Madya di Universitas Trisakti}

Permasalahan yang dihadapi dalam penelitian ini berkaitan pada tiga komponen yang berhubungan dengan keterampilan berbicara. Dalam melihat permasalahan yang terjadi di kelas, dilakukan prates sebagai gambaran kondisi awal penelitian. Berikut bahasan tiga komponen permasalahan tersebut yang terdiri atas siswa BIPA, guru BIPA, serta proses pembelajaran keterampilan berbicara.

Pengamatan dilakukan dengan memberikan prates sebelum penelitian tindakan dimulai. Berdasarkan hasil prates tersebut, ditemukan beberapa masalah yang terkait dalam keterampilan berbicara, seperti pelafalan, tata bahasa, kosakata, kelancaran, dan pemahaman. Hasil pengamatan siswa BIPA dapat dilakukan dengan melihat hasil prates dan hasil diskusi dengan kolaborator berkait kondisi awal kebahasaan siswa terutama keterampilan berbicaranya.

Permasalahan pertama terletak pada pelafalan yang kurang jelas saat mengucapkan bunyi dalam kata dan merangkai kata tersebut menjadi kalimat. Mereka melafalkan bunyi yang salah berulang kali, hingga ini bukan dikatakan sebuah kekhilafan tapi kesalahan. Misalnya pada kata 'guna' yang dilafalkan /gund/; kata 'cari' dilafalkan /chari/, kesalahan yang mendominasi pada 
14| Mabasan - Vol. 5, No. 1, Januari-Juni 2011

pelafalan terletak pada bunyi /c/ pada posisi awal, /a/ pada posisi akhir dan pada saat merangkai kata-kata tersebut menjadi kalimat, pelafalan mereka menjadi tidak jelas.

Permasalahan kedua, terletak pada tata bahasa, khususnya siswa masih banyak melakukan kesalahan pada penggunaan kata sambung intrakalimat dan antarkalimat. Acapkali dijumpai dua kali penyebutan konjungsi dalam satu kalimat majemuk bertingkat, misalnya: Saya tidak pernah mencuci pakaian dari air hangat. Tetapi karena tidak perlu, tapi kadang-kadang ada pakaian kotor sekali, saya memakai air hangat.

Selanjutnya, permasalahan ketiga terletak pada kosakata. Seringkali siswa masih menggunakan kata-kata asing terutama bahasa Inggris dan tak kurang dari mereka masih keliru dalam penggunaan pilihan kata atau diksi. Berikut contoh penggunaan kata asing yang ditemukan dalam kalimat siswa: Tetapi kalau ada hole di pakaian, saya akan membuangnya. Kemudian kesalahan pada penggunaan diksi seperti pada contoh dalam kalimat berikut: (a) Saya selalu menggunakan transportasi umum karena taksi mahal sekali. Kadang-kadang transportasi ini tidak bagus; (b) Saya kadang-kadang menggunakan transportasi umum karena ada orang yang mau bantu untuk naik motor dan mobil mereka. Bila ditilik kedua contoh kalimat di atas, siswa BIPA telah berusaha membuat kalimat, meski belum sesuai dengan diksi yang seharusnya. Pada kalimat (a) kata tidak bagus merujuk pada pelayanan dan bentuk pada transportasi umum yang seharusnya dapat diganti dengan dua pilihan kata, tidak bagus merujuk pada bentuk transportasi umum sedangkan tidak baik merujuk pada pelayanan transportasi umum. Pada kalimat (a) ini diksi yang digunakan berkaitan dengan semantik. Dalam proses pembelajaran selanjutnya memang harus dikenalkan penggunaan bentuk kata yang memiliki banyak makna dalam kalimat, seperti baik - bagus - benar yang dalam bahasa asing seperti bahasa Inggris juga terdapat bentuk kata serupa, seperti well, fine - good - true. Tujuannya agar siswa dapat menempatkan pilihan kata yang tepat. Selanjutnya, pada contoh kalimat (b) ditemukan kekurangtepatan diksi seperti mau bantu yang memiliki maksud menawarkan bila dilihat pada konteks kalimat yang dibuat.

Pada permasalahan yang terkait dengan kelancaran, seringkali siswa BIPA tersendat-sendat dalam mengujarkan kalimat, terutama pada kalimat majemuk. Dalam paraton, mereka seringkali lama membuat jeda, seperti pada kalimat berikut: (c) tetapi hmm tidak ada lubang mungkin...eee...mungkin...eee... saya memakai di rumah, untuk mencuci atau 
... Bipa Tingkat Madya di Universitas Trisakti (Dewi Nastiti L.) | 15

tidur. Mungkin ...oooo...kadang-kadang saya beri ke orang yang tidak ada pakaian.

Terakhir pada kriteria pemahaman, ada sebagian dari mereka yang belum belum bisa memahami konteks ujaran kawan tutur. Berikut contoh pemahaman yang salah (ada salah tafsir) seperti pada kalimat berikut: (d) Ketika saya berada di jalan raya...saya selalu menambah kecepatan kendaraan karena saya takut berbahaya.

Selain ada permasalahan pada siswa, permasalahan lainnya seperti pada guru, seperti cenderung menggunakan metode konvensional. Seringkali siswa merasa bosan karena belum ada variasi. Saat dilakukan pengamatan pada proses pembelajaran, siswa terlihat jenuh dengan pembelajaran tanpa ada variasi di dalamnya. Sangat disayangkan bila motivasi belajar bahasa Indonesia mereka cukup tinggi. Hal itu dapat ditandai dari sering munculnya pertanyaan mereka tentang struktur bahasa Indonesia yang benar. Sangat disayangkan juga bila proses belajar mereka tidak maksimal. Artinya, harus ada perubahan dalam teknik ajar maupun media ajar agar suasana belajar tidak monoton.

\section{Pembahasan}

\subsection{Penggunaan Media Film Dokumenter}

Menurut Gerlach and Ely dalam Azhar Arsyad (2002:2) jika dipahami secara garis besar media adalah manusia, materi, atau kejadian yang membangun kondisi yang membuat siswa mampu memperoleh pengetahuan, keterampilan, atau sikap. Dalam pengertian ini, guru, buku teks, dan lingkungan sekolah merupakan media.

Selain itu, AECT (Association of Education and Communication Technology) memberikan batasan tentang media sebagai segala bentuk dan saluran yang digunakan untuk penyampaian pesan atau informasi. Di samping sebagai penyampai atau pengantar, media sering diganti dengan kata mediator yang menurut Fleming adalah penyebab atau alat yang turut campur tangan dalam dua pihak. Dengan istilah mediator, media menunjukkan fungsi dan perannya yaitu mengatur hubungan yang efektif antara dua pihak utama dalam proses belajar siswa dan isi pelajaran.

Media pembelajaran berdasarkan pengertian di atas mencakup keseluruhan alat-alat dan fasilitas yang membantu proses belajar mengajar dan dapat menunjukkan hasil belajar siswa. 
16| Mabasan - Vol. 5, No. 1, Januari-Juni 2011

Sementara itu, Walkins (1982:263) menyatakan bahwa media audio visual dapat mengurangi kejenuhan dalam pembelajaran karena di dalam media tersebut terdapat manfaat yang begitu besar khususnya untuk melatih daya ingat dan siswa memiliki perhatian penuh yang tertuju pada gambar bergerak dan hal ini mempengaruhi situasi belajar siswa.

Sherman (2003:63) menyatakan bahwa dokumenter adalah versi televisi dari berita di surat kabar maupun artikel di majalah yang pada akhirnya menghadirkan wacana dan menjelaskannya, menceritakan suatu cerita, memberikan dukungan terhadap gugatan, juga mencari jawaban atas kebenaran.

Ditambahkan kembali oleh Sherman bahwa dalam pembelajaran bahasa, film-film dokumenter memiliki ruang belajar yang sangat banyak. Film-film dokumenter memiliki topik tetapi tidak berlangsung sebentar seperti kebanyakan berita. Artinya, topik film-film dokumenter dapat digunakan kembali. Mereka memiliki campuran antara spontanitas dan skrip bahasa serta banyak rangkaian pendek yang dapat digunakan untuk pembelajaran bahasa.

Seorang ahli pembuat film dokumenter, Rabiger (1997:139) menyatakan bahwa wawancara merupakan jantung dari pembuatan film dokumenter. Artinya tidak hanya informasi faktual yang didapatkan, tetapi juga kebenaran mendalam. Untuk berwawancara adalah dengan bertemu langsung dengan orang yang ingin kita wawancarai, gunanya untuk menggali informasi, menyimak, merespon, dan memandu dalam mengekspresikan hidup.

Pada praktiknya, jenis film dokumenter yang dipilih berdurasi antara 12 hingga 14 menit. Film dokumenter yang digunakan diperoleh dari Yayasan Masyarakat Mandiri Film Indonesia, sebuah komunitas film Indonesia yang di dalamnya terdapat kerja sama antara In-Docs dan Yayasan Ford Foundation.

Pemilihan judul film dokumenter pada penelitian ini disesuaikan dengan tingkat kebutuhan para pembelajar dan tingkatan dalam program BIPA, yakni tingkat madya. Program BIPA Kerja sama Negara Berkembang di Trisakti pada tahun ini khususnya tingkat madya mengikutsertakan 6 siswa yang berlatar belakang pendidikan dan tujuan yang berbeda. Secara rinci ada tiga kebutuhan dalam ranah akademis yang melatarbelakangi keinginan mereka untuk mengikuti program BIPA. Ketiga kebutuhan akademis itu terdiri atas bidang keilmuan yang harus mereka tempuh di Indonesia. Ketiga bidang keilmuan tersebut adalah ekonomi, geologi, dan bahasa. Berkaitan dengan judul film dokumenter yang digunakan, peneliti menyesuaikannya dengan latar belakang 
pendidikan siswa di samping pula mengikuti asas-asas yang sudah ditetapkan sebelumnya dengan menitikberatkan citra Indonesia.

Berdasarkan pemikiran tersebut, judul film dokumenter yang dipilih adalah Film Kolok dan Prahara Tsunami Bertabur Bakau. Kolok adalah film dokumenter yang berisi fenomena komunitas masyarakat Bali yang bisu dan tuli untuk mengakomodir siswa yang berlatar belakang pendidikan ekonomi dan bahasa. Ada suatu adegan yang menceritakan aktivitas masyarakat Kolok sedang bertransaksi di pasar tanpa mereka ragu akan keterbatasan mereka dan tanpa ada kekeliruan yang berarti dalam melakukan transaksi. Selain itu pula, dalam adegan film selanjutnya terdapat pengenalan budaya setempat, yakni adat mkarya, seni janger, dan sabung ayam.

Sementara itu, Film Prahara Tsunami Bertabur Bakau untuk mengakomodir siswa yang berlatar belakang geologi berisi tentang dedikasi pecinta lingkungan yang berusaha mengubah lahan yang porak poranda akibat gejala alam, tsunami menjadi tanaman bakau di pesisir pantai.

Jadi dalam penelitian ini, penggunaan media film dokumenter merupakan alat pembelajaran efektif untuk menyampaikan materi yang berisikan pengenalan budaya dan realita sosial dengan tujuan untuk menjembatani proses komunikasi pada saat-saat tertentu, seperti kesenjangan antara bahasa dan budaya mereka. Dalam hal ini digunakan film dokumenter yang disesuaikan dengan topik BIPA pada tingkat madya.

\subsection{Keterampilan Berbicara}

Hughes (2002:6-7) menyatakan bahwa dalam mengajar berbicara tidak dapat terpisahkan dari aktivitas lainnya di samping linguistik (Faktor yang sangat kompleks adalah ketika berbicara merupakan fokus aktivitas di kelas yang bertujuan: membantu siswa untuk memperoleh kesadaran atau mempraktikkan beberapa aspek pengetahuan linguistik (apabila aturan tata bahasa atau aplikasi dari peraturan fonemik yang telah dikenalkan) atau untuk membangun keterampilan produktif (contohnya seperti ritme, intonasi, atau kenyaringan antarvokal), atau untuk meningkatkan kesadaran dari beberapa poin sosiolinguistik atau pragmatik (khususnya petunjuk untuk menginterupsi secara halus, merespon tanggapan segera, atau salah satunya).

Berikut ini adalah tingkat dan keluasan aspek penelitian berbicara. Hughes menambahkan bahwa ada tiga bagian penting dalam menunjang penelitian berbicara. Ketiga bagian tersebut adalah pengorganisasian, tata 
bahasa dan bunyi. Pengorganisasian dan sikap berbahasa terdiri atas psikolinguistik dan sosiolinguistik, pragmatik, kinestetik, analisis wacana dan percakapan. Sementara itu, struktur bahasa terdiri atas sintaksis, tata bahasa, leksikal atau pelajaran kosa kata, dan fonologi. Terakhir, bunyi bahasa terdiri atas fonetik, fonemik, dan prosodi atau pelajaran intonasi. Ketiga bagian di atas adalah faktor terpenting dalam penelitian berbicara.

Hughes juga menyatakan bahwa kegiatan berbicara tidak luput dari aspek-aspek sosial. Berikut gambaran dari aspek sosial berbicara, seperti (locus of change), interpersonal (interpersonal), informal (informal), terstigma (stigmatized), retoris (rhetorical),dan primer (primary). Pada pernyataan Hughes ini, aspek sosial memang sangat mendasari keterampilan berbicara seseorang, yang dalam hal ini adalah siswa BIPA tingkat madya. Dalam praktiknya, siswa BIPA tingkat madya berbaur dan berkomunikasi dengan komponen realita sosial dan juga budaya di sekelilingnya. Oleh sebab itu materi ajar yang menggunakan materi otentik sangatlah diperlukan.

Proses pengajaran keterampilan berbicara, khususnya dalam penelitian ini yang menggunakan media film dokumenter memang tidak luput dari suatu diskusi antara pengajar dan pembelajar. Pendekatan yang digunakan dalam strategi diskusi ini adalah pendekatan kooperatif. Penny (2002:2) menyatakan bahwa diskusi merupakan aktivitas berbahasa yang berlangsung alami.

Diskusi merupakan aktivitas berbahasa yang berlangsung alami dan pembelajaran berbicara yang efektif karena siswa mempraktikkan kemampuan berbicara secara bebas dan mereka dapat memecahkan berbagai permasalahan atau situasi secara bersama-sama dalam mengungkapkan ide.

Dikatakan lebih lanjut, bahwa dalam mempelajari diskusi, peserta secara langsung dapat berpartisipasi dalam menuangkan gagasannya. Selain itu pula, peserta diskusi akan belajar untuk berpikir logis seperti memiliki kemampuan mengeneralisasi, beranalogi, dan sebagainya. Kemampuan untuk berdebat oleh Penny dimaksudkan untuk menyimak pembicaraan seseorang, tidak menginterupsi, dan berbicara yang relevan serta jelas.

John W Oller (1979:320-321) mengategorikan penilaian kompetensi bahasa lisan merujuk pada skala FSI (The Foreign Service Institute). Berikut 
adalah deskripsi beserta kriteria penilaian kompetensi berbahasa lisan berdasarkan FSI.

1. Mampu memenuhi kebutuhan sehari-hari serta keperluan sopan-santun sekedarnya: bertanya dan menjawab pertanyaan tentang hal-hal sederhana yang diketahui dengan kemampuan berbahasanya yang terbatas.

2. Mampu memenuhi kebutuhan sosial dan pekerjaan sehari-hari: berkomunikasi secara mantap, meskipun dengan kesulitan, dalam kegiatan sosial sehari-hari, seperti memperkenalkan diri, berbicara tentang kejadian aktual, pekerjaan, keluarga, dan sebagainya.

3. Mampu menggunakan bahasa dengan tata bahasa dan kosakata yang lumayan untuk mengambil bagian secara efektif dalam pembicaraan formal maupun informal tentang hal-hal yang praktis, dan berhubungan dengan masalah sosial atau profesional: mendiskusikan hal-hal khusus dengan mudah atas dasar pemahaman mengenai hal yang dibicarakan, dengan perbendaharaan kata dan tata bahasa yang cukup, kesalahan-kesalahan yang kecil yang tidak sampai mengganggu pemahaman, meskipun dengan logat yang terdengar asing.

4. Mampu menggunakan bahasa sesuai dengan kebutuhan dalam bidang pekerjaannya, secara tepat dan lancar: memahami dan berpartisipasi dalam berbagai pembicaraan dalam bidangnya dengan lancar dan pilihan kata yang tepat; meskipun tidak sampai seperti penutur asli, tapi mampu memberi tanggapan bahkan dalam hal dan keadaan yang asing, dan dengan kesalahan lafal dan tata bahasa tidak banyak.

5. Mampu menggunakan bahasa sebagaimana layaknya seorang penutur asli: bahasa yang digunakan sedemikian baik dan lancar pada berbagai aspeknya, baik pemilihan kata, ungkapan, maupun nuansa kulturalnya, sehingga sepenuhnya dapat diterima oleh penutur asli.

Keterampilan berbicara yang dimaksudkan dalam penelitian ini adalah kegiatan yang bertujuan untuk berkomunikasi dengan kawan bicara secara logis dan wajar dengan menggunakan pelafalan yang tepat, bertata bahasa yang benar, penggunaan kosakata yang tepat, kelancaran pengucapan yang baik, dan terdapat pemahaman antarkawan bicara. 
20| Mabasan - Vol. 5, No. 1, Januari-Juni 2011

\subsection{Proses Penggunaan Media Film Dokumenter dalam Upaya Peningkatan Keterampilan Berbicara}

\begin{tabular}{|c|c|c|c|}
\hline Praobservasi & Masalah & $\begin{array}{l}\text { Tindakan pada } \\
\text { Siklus I dengan } \\
\text { Teknik Diskusi }\end{array}$ & $\begin{array}{l}\text { Tindakan pada } \\
\text { Siklus II dengan } \\
\text { Teknik Diskusi }\end{array}$ \\
\hline Pelafalan & $\begin{array}{l}\text { Pelafalan } \\
\text { kurang jelas } \\
\text { saat } \\
\text { merangkai } \\
\text { kata menjadi } \\
\text { kalimat. }\end{array}$ & $\begin{array}{l}\text { Menayangkan } \\
\text { adegan berisi } \\
\text { pelafalan tokoh dan } \\
\text { siswa bisa melihat } \\
\text { proses pelafalannya } \\
\text { dan menirukannya. }\end{array}$ & $\begin{array}{l}\text { Menayangkan adegan } \\
\text { berisi pelafalan tokoh } \\
\text { dan siswa bisa } \\
\text { melihat proses } \\
\text { pelafalannya dan } \\
\text { menirukannya. }\end{array}$ \\
\hline Tatabahasa & $\begin{array}{l}\text { Penggunaan } \\
\text { kata } \\
\text { sambung } \\
\text { intrakalimat } \\
\text { dan } \\
\text { antarkalimat } \\
\text { kurang tepat. }\end{array}$ & $\begin{array}{l}\text { Memberikan } \\
\text { tayangan seputar } \\
\text { ujaran yang } \\
\text { memperlihatkan } \\
\text { konjungtor } \\
\text { intrakalimat dan } \\
\text { antarkalimat. } \\
\text { Meminta siswa } \\
\text { membetulkan bentuk } \\
\text { kalimat yang salah } \\
\text { dalam film. }\end{array}$ & $\begin{array}{l}\text { Memberikan } \\
\text { tayangan seputar } \\
\text { ujaran yang } \\
\text { memperlihatkan } \\
\text { konjungtor } \\
\text { intrakalimat dan } \\
\text { antarkalimat. } \\
\text { Meminta siswa } \\
\text { membetulkan bentuk } \\
\text { kalimat yang salah } \\
\text { dalam film. }\end{array}$ \\
\hline Kosakata & $\begin{array}{l}\text { Penggunaan } \\
\text { kata kurang } \\
\text { tepat. }\end{array}$ & $\begin{array}{l}\text { Menayangkan } \\
\text { adegan berisi } \\
\text { penggunaan kata } \\
\text { sesuai konteks. } \\
\text { Meminta siswa } \\
\text { untuk membetulkan } \\
\text { penggunaan kata } \\
\text { yang tidak sesuai } \\
\text { konteks. }\end{array}$ & $\begin{array}{l}\text { Menayangkan adegan } \\
\text { berisi penggunaan } \\
\text { kata sesuai konteks. } \\
\text { Meminta siswa untuk } \\
\text { membetulkan } \\
\text { penggunaan kata } \\
\text { yang tidak sesuai } \\
\text { konteks. }\end{array}$ \\
\hline Kelancaran & $\begin{array}{l}\text { Tersendat- } \\
\text { sendat dalam } \\
\text { mengujarkan } \\
\text { kalimat } \\
\text { majemuk. }\end{array}$ & $\begin{array}{l}\text { Mengulang tayangan } \\
\text { yang } \\
\text { memperlihatkan } \\
\text { ujaran tokoh cerita }\end{array}$ & $\begin{array}{l}\text { Mengulang tayangan } \\
\text { yang memperlihatkan } \\
\text { ujaran tokoh cerita }\end{array}$ \\
\hline
\end{tabular}


... Bipa Tingkat Madya di Universitas Trisakti (Dewi Nastiti L.) $\mid 21$

\begin{tabular}{|c|c|c|c|}
\hline & & $\begin{array}{l}\text { Meminta siswa } \\
\text { untuk mengulang } \\
\text { kalimat majemuk } \\
\text { seperti tayangan } \\
\text { dalam film } \\
\text { dokumenter. }\end{array}$ & $\begin{array}{l}\text { Meminta siswa untuk } \\
\text { mengulang kalimat } \\
\text { majemuk seperti } \\
\text { tayangan dalam film } \\
\text { dokumenter. }\end{array}$ \\
\hline Pemahaman & $\begin{array}{l}\text { Belum bisa } \\
\text { memahami } \\
\text { konteks } \\
\text { ujaran kawan } \\
\text { tutur }\end{array}$ & $\begin{array}{l}\text { •Menayangkan } \\
\text { bentuk ujaran } \\
\text { langsung yang } \\
\text { dibantu dengan } \\
\text { situasi dan } \\
\text { konteks sosial } \\
\text { budaya yang } \\
\text { melatarbelakangi } \\
\text { tokoh. Dalam hal } \\
\text { ini ujaran dapat } \\
\text { diperjelas dari } \\
\text { reaksi tokoh dari } \\
\text { situasi dan } \\
\text { konteks tersebut. } \\
\text { •Memberikan } \\
\text { pertanyaan } \\
\text { tentang klimaks } \\
\text { dari film } \\
\text { dokumenter. Hal } \\
\text { ini dimaksudkan } \\
\text { untuk } \\
\text { membangun } \\
\text { opini dan mencari } \\
\text { solusi bersama. }\end{array}$ & $\begin{array}{l}\text { •Menayangkan } \\
\text { bentuk ujaran } \\
\text { langsung yang } \\
\text { dibantu dengan } \\
\text { situasi dan konteks } \\
\text { sosial budaya yang } \\
\text { melatarbelakangi } \\
\text { tokoh. Dalam hal } \\
\text { ini ujaran dapat } \\
\text { diperjelas dari } \\
\text { reaksi tokoh dari } \\
\text { situasi dan konteks } \\
\text { tersebut. } \\
\text { •Memberikan } \\
\text { pertanyaan tentang } \\
\text { klimaks dari film } \\
\text { dokumenter. Hal } \\
\text { ini dimaksudkan } \\
\text { untuk membangun } \\
\text { opini dan mencari } \\
\text { solusi bersama. }\end{array}$ \\
\hline \multicolumn{3}{|c|}{ Tambahan kegiatan pada siklus 2} & $\begin{array}{l}\text { Mengoreksi } \\
\text { kesalahan berbicara } \\
\text { antarsiswa yang } \\
\text { didasarkan atas } \\
\text { tayangan film } \\
\text { dokumenter. }\end{array}$ \\
\hline
\end{tabular}




\subsection{Hasil Evaluasi Siswa}

Berikut hasil analisis evaluasi keterampilan berbicara siswa yang terlihat pada perbandingan prates hingga siklus 2 .

\section{Prates}

\begin{tabular}{|c|c|c|c|c|}
\hline $\begin{array}{l}\text { Tata } \\
\text { Bahasa }\end{array}$ & Kosakata & Pemahaman & Kelancaran & Pelafalan \\
\hline $\begin{array}{l}\text { Pelesapan } \\
\text { dua fungsi } \\
\text { kalimat. }\end{array}$ & $\begin{array}{l}\text { Penggunan } \\
\text { kata asing. }\end{array}$ & $\begin{array}{l}\text { Hubungan } \\
\text { sebab akibat } \\
\text { yang belum } \\
\text { sesuai dengan } \\
\text { penalaran } \\
\text { logis. }\end{array}$ & $\begin{array}{l}\text { Terbata-bata } \\
\text { dan jeda lama. }\end{array}$ & $\begin{array}{l}\text { Pengaruh } \\
\text { bunyi dari } \\
\text { negara } \\
\text { asalnya, } \\
\text { pelafalan } \\
\text { bunyi /c/ } \\
\text { menjadi } \\
\text { bunyi /che/. }\end{array}$ \\
\hline $\begin{array}{l}\text { Preposisi } \\
\text { kurang } \\
\text { tepat, } \\
\text { konjungtor } \\
\text { intrakalimat } \\
\text { yang } \\
\text { berlebihan. }\end{array}$ & $\begin{array}{l}\text { Penggunaan } \\
\text { diksi yang } \\
\text { belum } \\
\text { tepat. }\end{array}$ & $\begin{array}{l}\text { Ketidakjelasan } \\
\text { maksud. }\end{array}$ & $\begin{array}{l}\text { Pengulangan } \\
\text { kata beberapa } \\
\text { kali dalam satu } \\
\text { kalimat. }\end{array}$ & $\begin{array}{l}\text { Pengaruh } \\
\text { bunyi dari } \\
\text { negaranya, } \\
/ \mathrm{a} / \text { dilafalkan } \\
/ \partial / .\end{array}$ \\
\hline $\begin{array}{l}\text { Pelesapan } \\
\text { sufiks } \\
\text {-kan }\end{array}$ & & & $\begin{array}{l}\text { Kalimat yang } \\
\text { belum selesai } \\
\text { karena tidak } \\
\text { lancar dalam } \\
\text { mengemukakan } \\
\text { ide }\end{array}$ & $\begin{array}{l}\text { Pola suku } \\
\text { kata yang } \\
\text { terbalik }\end{array}$ \\
\hline $\begin{array}{l}\text { Urutan } \\
\text { fungsi } \\
\text { kalimat } \\
\text { yang } \\
\text { terbalik } \\
\text { juga } \\
\text { penggunaan } \\
\text { kata } \\
\text { hubung } \\
\text { yang belum } \\
\text { tepat. }\end{array}$ & & & & $\begin{array}{l}\text { Salah } \\
\text { pemenggalan } \\
\text { suku kata } \\
\text { khususnya } \\
\text { terpengaruh } \\
\text { dengan } \\
\text { gugus } \\
\text { konsonan. }\end{array}$ \\
\hline
\end{tabular}


... Bipa Tingkat Madya di Universitas Trisakti (Dewi Nastiti L.) $\mid 23$

\begin{tabular}{|l|l|l|l|l|}
\hline $\begin{array}{l}\text { Pemilihan } \\
\text { diksi dan } \\
\text { penggunaan } \\
\text { kata hubung } \\
\text { yang belum } \\
\text { tepat. }\end{array}$ & & & & $\begin{array}{l}\text { Bunyi /h/ } \\
\text { yang tertukar } \\
\text { dengan } / \mathrm{r} / .\end{array}$ \\
\hline & & & & \\
& & & & $\begin{array}{l}\text { Bunyi /// } \\
\text { yang tertukar } \\
\text { dengan } / \mathrm{r} / .\end{array}$ \\
\hline
\end{tabular}

Siklus I

\begin{tabular}{|c|c|c|c|c|}
\hline $\begin{array}{l}\text { Tata } \\
\text { Bahasa }\end{array}$ & Kosakata & Pemahaman & Kelancaran & Pelafalan \\
\hline $\begin{array}{l}\text { Sudah ada } \\
\text { peningkatan } \\
\text { dalam } \\
\text { ketepatan } \\
\text { penggunaan } \\
\text { kata hubung } \\
\text { meski masih } \\
\text { ganda } \\
\text { berupa } \\
\text { konjungtor } \\
\text { pertentangan } \\
\text { dan } \\
\text { konjungtor } \\
\text { sebab } \\
\text { akibat. }\end{array}$ & $\begin{array}{l}\text { Penggunaan } \\
\text { diksi yang } \\
\text { belum } \\
\text { tepat. }\end{array}$ & $\begin{array}{l}\text { Pemahaman } \\
\text { terbentuk dari tanya } \\
\text { jawab seputar film } \\
\text { secara alami } \\
\text { (belajar mengoreksi } \\
\text { kesalahpahaman } \\
\text { antarkawan bicara) }\end{array}$ & $\begin{array}{l}\text { Masih ada } \\
\text { jeda lama } \\
\text { tapi } \\
\text { berusaha } \\
\text { mengingat } \\
\text { kata dari } \\
\text { film yang } \\
\text { dilihatnya. }\end{array}$ & $\begin{array}{l}\text { Pelafalan } \\
\text { yang masih } \\
\text { terpengaruh } \\
\text { dari } \\
\text { negaranya } \\
\text { tapi } \\
\text { berusaha } \\
\text { untuk } \\
\text { melafalkan } \\
\text { dalam } \\
\text { bahasa } \\
\text { target } \\
\text { dengan } \\
\text { pengulangan } \\
\text { (drill) }\end{array}$ \\
\hline $\begin{array}{l}\text { Banyak ide } \\
\text { yang ingin } \\
\text { diungkapkan } \\
\text { tapi tidak } \\
\text { tuntas } \\
\text { dirangkai } \\
\text { dalam } \\
\text { kalimat serta } \\
\text { banyak } \\
\text { pengulangan } \\
\text { dalam }\end{array}$ & $\begin{array}{l}\text { Penggunaan } \\
\text { kata asing } \\
\text { dan } \\
\text { langsung } \\
\text { diralat. }\end{array}$ & $\begin{array}{l}\text { Pengungkapan ide } \\
\text { yang banyak hingga } \\
\text { mengubah struktur } \\
\text { kalimat yang } \\
\text { berakibat pada } \\
\text { penalaran. Namun } \\
\text { sudah berani untuk } \\
\text { mengungkapkannya } \\
\text { dalam bahasa } \\
\text { target. }\end{array}$ & $\begin{array}{l}\text { Masih } \\
\text { banyak jeda } \\
\text { tapi } \\
\text { berusaha } \\
\text { keras untuk } \\
\text { melengkapi } \\
\text { struktur } \\
\text { kalimat. }\end{array}$ & \\
\hline
\end{tabular}


24| Mabasan - Vol. 5, No. 1, Januari-Juni 2011

\begin{tabular}{|l|l|l|l|l|}
\hline penggunaan & & & \\
kata hubung. & & & \\
Namun kata & & & & \\
hubung & & & \\
yang & & & \\
digunakan & sudah tepat. & & & \\
\hline
\end{tabular}

Siklus II

\begin{tabular}{|c|c|c|c|c|}
\hline $\begin{array}{l}\text { Tata } \\
\text { Bahasa }\end{array}$ & Kosakata & Pemahaman & Kelancaran & Pelafalan \\
\hline \multirow[t]{2}{*}{$\begin{array}{l}\text { Pengulangan } \\
\text { kata hubung } \\
\text { tapi sudah } \\
\text { tidak } \\
\text { tercampur } \\
\text { dengan kata } \\
\text { hubung } \\
\text { lainnya. }\end{array}$} & $\begin{array}{l}\text { Ketidaktep } \\
\text { atan diksi } \\
\text { dan } \\
\text { langsung } \\
\text { dibetulkan. }\end{array}$ & $\begin{array}{l}\text { Ada } \\
\text { kesalahpahaman } \\
\text { dan langsung } \\
\text { dibetulkan dengan } \\
\text { tanya jawab } \\
\text { seputar film. }\end{array}$ & $\begin{array}{l}\text { Masih belum } \\
\text { lancar dalam } \\
\text { menghubung } \\
\text { kan induk } \\
\text { kalimat dan } \\
\text { anak kalimat, } \\
\text { tapi sudah } \\
\text { mengerti } \\
\text { arah } \\
\text { pembicaraan. }\end{array}$ & $\begin{array}{l}\text { Masih ada } \\
\text { pelafalan } \\
\text { yang } \\
\text { terpengaruh } \\
\text { dari } \\
\text { negaranya } \\
\text { namun } \\
\text { berusaha } \\
\text { untuk } \\
\text { melafalkan } \\
\text { dalam } \\
\text { bahasa target } \\
\text { dengan } \\
\text { pengulangan } \\
(d r i l l) \text {. }\end{array}$ \\
\hline & $\begin{array}{l}\text { Ketidaktep } \\
\text { atan } \\
\text { reduplikasi } \\
\text { dan } \\
\text { langsung } \\
\text { dibetulkan. }\end{array}$ & $\begin{array}{l}\text { Pengungkapan ide } \\
\text { yang lama namun } \\
\text { berusaha } \\
\text { dikeluarkan } \\
\text { dalam } \\
\text { pengulangan } \\
\text { kalimat, terutama } \\
\text { setelah kata } \\
\text { hubung dalam } \\
\text { kalimat majemuk } \\
\text { bertingkat. }\end{array}$ & & \\
\hline
\end{tabular}




\subsection{Pengaruh Penggunaan Film Dokumenter terhadap Peningkatan Keterampilan Berbicara Siswa BIPA Tingkat Madya}

Pengaruh penggunaan film dokumenter dapat ditandai dari peningkatan yang ada pada tiap siklus dalam penelitian tindakan. Berdasarkan dari kegiatan penelitian pada siklus kedua, hasil nilai rata-rata yang diperoleh pada siklus 2 lebih baik dibandingkan pada siklus 1 terkait 5 aspek keterampilan berbicara. Bila dilihat dari nilai rata-rata yang diperoleh dari prates hingga siklus 2, dapat dicermati bahwa keterampilan berbicara siswa mengalami peningkatan secara bertahap. Meski peningkatannya hanya beranjak dalam satu tahapan tapi pergerakannya menuju ke arah yang signifikan. Bila dibandingkan dari awal, nilai rata-rata prates hingga siklus 1 berada pada nilai 66,80 dengan deskripsi kemampuan bisa berkomunikasi dengan lancar, tetapi tidak selalu tepat dan efektif. Nilai rata-rata tersebut mengalami peningkatan meski masih dalam satu kisaran. Selanjutnya antara siklus 1 hingga siklus 2 mengalami peningkatan hingga $2,7 \%$. Peningkatan nilai rata-rata yang diperoleh pada siklus 2 yang sudah mengarah ke kisaran 70-74 atau pada skala 3 sesuai dengan skala yang diadopsi dari FSI. Pada siklus 2 diperoleh nilai rata-rata 72,50. Artinya kemampuan berbicara siswa berada dalam ketepatan tata bahasa dan kosa kata yang memadai untuk berpartisipasi efektif dalam percakapan formal dan informal dalam topik-topik praktis, sosial, dan profesi. Berikut gambaran perbandingan nilai rata-rata dari prates hingga siklus 2 yang berada pada tabel dan diagram berikut.

\begin{tabular}{|c|c|c|c|}
\hline Keterangan & Prates & Siklus 1 & \multicolumn{1}{c|}{ Siklus 2 } \\
\hline $\begin{array}{c}\text { Jumlah } \\
\text { Rerata }\end{array}$ & 66,82 & 69,80 & \multicolumn{1}{c|}{72,50} \\
\hline Deskripsi & $\begin{array}{l}\text { Mampu } \\
\text { berkomunikasi } \\
\text { dengan lancar, } \\
\text { tetapi tidak } \\
\text { selalu tepat dan } \\
\text { efektif. }\end{array}$ & $\begin{array}{l}\text { Mampu } \\
\text { berkomunikasi } \\
\text { dengan lancar, } \\
\text { tetapi tidak } \\
\text { selalu tepat dan } \\
\text { efektif. }\end{array}$ & $\begin{array}{l}\text { Mampu berbicara } \\
\text { dengan ketepatan tata } \\
\text { bahasa dan kosa kata } \\
\text { yang memadai untuk } \\
\text { berpartisipasi efektif } \\
\text { dalam percakapan } \\
\text { formal dan informal } \\
\text { dalam topik-topik } \\
\text { praktis, sosial, dan } \\
\text { profesi. }\end{array}$ \\
\hline
\end{tabular}




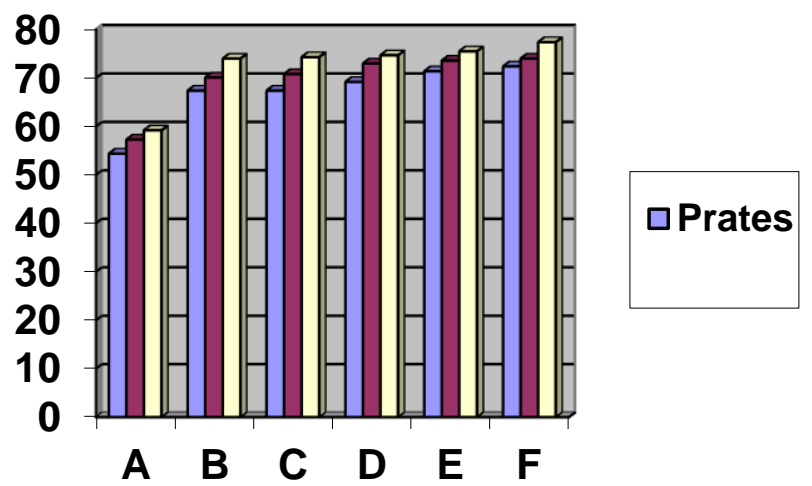

Proses peningkatan keterampilan berbicara dengan film dokumenter dalam siklus 1 bertujuan untuk melatih siswa berpikir logis dan berbahasa target dalam bahasa Indonesia. Namun setelah dilakukan kegiatan berbicara melalui film dokumenter pada siklus 1 peningkatan hanya beranjak dalam satu kisaran dan peningkatan selanjutnya dilakukan pada siklus 2 dengan mengubah rancangan pembelajaran. Perubahan rancangan pembelajaran tersebut dengan menambah kegiatan pembelajaran berupa penilaian teman sebaya khususnya saling mengoreksi kesalahan antarsiswa dan saling memberikan saran untuk memperbaiki kesalahan tersebut.

Dari hasil kualitatif tersebut dapat terlihat bahwa teknik diskusi melalui film dokumenter sangat memotivasi siswa untuk berpikir logis dan berbahasa target, bahasa Indonesia. Sisi film dokumenter yang menampilkan bentuk konkret atau realita sosial dan budaya Indonesia dapat menggugah imajinasi dan emotif siswa untuk terlibat langsung dalam diskusi. Kepekaan akan realita sosial dan kesadaran terkait budaya Indonesia dengan sentuhan film dokumenter dapat memicu siswa untuk berpikir logis dan berbahasa target, bahasa Indonesia.

Sementara itu, hasil yang didapat dari angket siswa BIPA setelah selesai mengikuti tahapan penelitian tindakan pada kedua siklus, memperlihatkan keantusiasan pembelajaran menggunakan media film dokumenter. Berikut kutipan kesan siswa yang terjaring dalam angket setelah belajar dengan film dokumenter, terutama untuk peningkatkan keterampilan berbicara. 
a. "Saya pikir setelah belajar bahasa dan budaya Indonesia menggunakan film dokumenter, saya belajar banyak kata-kata baru, belajar mendengar dari orang lain, dan belajar tentang budaya. Saya pikir film dokumenter itu menarik untuk belajar karena film dokumenter ada banyak informasi."

b. "Saya senang sekali belajar bahasa dan budaya Indonesia menggunakan film dokumenter karena saya bisa paham dan menonton cerita tentang budayanya. Film tersebut bagus dan penting untuk orang asing belajar karena kita cepat mengerti."

c. "Saya banyak kesan setelah belajar bahasa dan budaya Indonesia menggunakan film dokumenter karena Indonesia sangat budaya dan paling menarik ke belajar."

d. "Saya lebih suka ini dari membaca cerita karena kapan kami nonton film dokumenter kami dengar bahasa Indonesia dan belajar tentang budaya. Ini penting untuk kami karena kami tinggal di Indonesia. Digunakan film dokumenter bagus juga untuk diskusi dan bicara. Saya berpikir topik menarik."

e. "Film dokumenter itu mempengaruhi pelajaran bahasa saya karena material video, audio adalah penting untuk kebiasaan berbicara. Jadi dari beberapa dokumenter, saya bisa mendapat kata-kata baru. Material ini juga adalah untuk keseharian karena kita bisa mendedukasi pelajaran misalnya yang tentang tsunami."

\section{Penutup}

\subsection{Simpulan}

Berdasarkan penelitian tindakan pada peningkatan keterampilan berbicara dengan penggunaan film dokumenter di Universitas Trisakti, maka diperoleh temuan penelitian dalam dua siklus. Adapun temuan penelitian tersebut disimpulkan berdasarkan sumber data kualitatif dari hasil pengamatan proses pembelajaran. Selain itu temuan penelitian pun disimpulkan berdasarkan analisis data kuantitatif. Berikut ini adalah data kuantitatif dan kualitatif yang diperoleh dari siklus 1 dan 2. Data kuantitatif menunjukkan peningkatan pada siklus 1 ke siklus 2 sebesar 2,70\% dan dari prates ke siklus 2 sebesar 5,68\%.

Sementara data kualitatif yang mendukung adanya peningkatan terlihat dari catatan kolaborator serta angket siswa setelah belajar menggunakan media film dokumenter. 
28| Mabasan - Vol. 5, No. 1, Januari-Juni 2011

Berdasarkan data kualitatif dan kuantitatif yang diperoleh dari kedua siklus ternyata menunjukkan adanya peningkatan keterampilan berbicara melalui teknik diskusi dengan penerapan film dokumenter pada siswa BIPA tingkat Madya di Universitas Trisakti.

Penerapan pendekatan integratif dalam teknik diskusi melalui film dokumenter ternyata dapat membangun motivasi siswa untuk berbahasa target dan berpikir logis.

\subsection{Saran}

Perlu ada penelitian lanjutan dengan topik yang sama untuk memperbaiki kualitas keterampilan berbicara melalui penggunaan film dokumenter. Terkait dengan hal tersebut, penelitian tindakan bersifat memperbaiki proses belajar mengajar melalui stimulus yang diujicobakan. Oleh sebab itu, untuk melihat respon positif para siswa, jumlah objek penelitian diharapkan lebih besar dari penelitian ini, meski kelas BIPA yang kita ketahui tidak seperti kelas dalam pendidikan formal di Indonesia.

\section{Daftar Pustaka}

Hughes, Rebecca. 2002. Teaching and Researching Speaking. London: Pearson.

Oller, John W Jr. 1979. Language Tests At School. London: Longman.

Penny, Ur. 2002. Discussions That Work. Task-Centre Fluency Practice. USA: Cambridge.

Rabiger, Michael. 1997. Directing Documentary. Second Edition. Boston: Focal Press.

Sherman, Jane. 2003. Using Authentic Video in the Language Classroom. USA: Cambridge University Press. 